\title{
Article
}

\section{Microbial assessment of different samples of ostrich (Struthio camelus) and determination of antimicrobial susceptibility profiles of the isolated bacteria}

\author{
Israt Jahan ${ }^{1}$, Nazmi Ara Rumi ${ }^{1 *}$, Md. Khaled Hossain ${ }^{1}$, Md. Shajedur Rahman ${ }^{2}$, Md. Fakhruzzaman ${ }^{1}$, Samina \\ Akter $^{1}$ and Abdul Gaffar Miah ${ }^{3}$ \\ ${ }^{1}$ Department of Microbiology, Hajee Mohammad Danesh Science \& Technology University, Dinajpur, \\ Bangladesh \\ ${ }^{2}$ Department of Medicine, Surgery \& Obstetrics, Hajee Mohammad Danesh Science \& Technology University, \\ Dinajpur, Bangladesh \\ ${ }^{3}$ Department of Genetics and Animal Breeding, Hajee Mohammad Danesh Science \& Technology University, \\ Dinajpur, Bangladesh
}

"Corresponding author: Nazmi Ara Rumi, Lecturer, Department of Microbiology, Hajee Mohammad Danesh Science \& Technology University, Dinajpur, Bangladesh. Phone: +8801774410088; E-mail: rumi_dvm@yahoo.com

Received: 29 November 2017/Accepted: 26 December 2017/ Published: 28 December 2017

\begin{abstract}
The study was conducted to monitor the microbial assessment in oropharyngeal swab, cloacal swab and faecal samples of ostrich and also update knowledge on antimicrobial sensitivity of isolated organisms. The study was performed at Hajee Mohammad Danesh Science \& Technology University (HSTU) ostrich farm from January to June, 2016. A total 75 samples were randomly collected from 8 ostriches at different age of which 25 oropharyngeal, 25 cloacal swabs sample and 25 were faeces samples. The organisms were isolated by using standard microbiological method. The result revealed that the average microbial load in plate count agar was highest in faeces $\left(1.48 \times 10^{9} \pm 0.27 \mathrm{CFU}\right)$ than oropharyngeal swab $\left(1.36 \times 10^{9} \pm 0.38 \mathrm{CFU}\right)$ and cloacal swab $\left(1.28 \times 10^{9} \pm 0.34 \mathrm{CFU}\right)$. Among 75 samples, 29 (38.66\%) Escherichia coli, 21 (28\%) Salmonella spp., 20 (26.67\%) Staphylococcus spp. and 5(6.6\%) Bacillus spp. were identified. In 25 oropharyngeal swab samples, Staphylococcus spp. was found highest $15(60 \%)$ than other organisms but Escherichia coli were found highest both in cloacal 11(44\%) and faecal 12(48\%) samples. On antibiogram study Escherichia coli, Salmonella spp., Staphylococcus spp. and Bacillus spp. were more sensitive to Levofloxacin, Azithromycin, Nalidixic Acid and Amoxicillin respectively. While more resistant to Azithromycin, Penicillin, Chloramphenicol and Erythromycin respectively. The obtained results indicated that ostrich excreta are one of the most important sources of Escherichia coli, Staphylococcus spp., Salmonella spp., Bacillus spp. in ostrich farms. Finally, it may be concluding that the logical use of antibiotics must be adopted in ostrich farms reared in Bangladesh for prevention of the appearance of multidrug resistance bacteria. Moreover, proper measures should be taken to aware off zoonotic diseases in peoples who are involved in ostrich farming.
\end{abstract}

Keywords: ostriches; cloacal swabs; oropharyngeal swabs; antibiotic resistance

\section{Introduction}

The ostrich (Struthio camelus) is the largest and heaviest living bird. The natural home of the ostrich is Africa. Large numbers of ostriches were exported from Africa in the latter half of 19th century to Australia, New Zealand, Europe, North and South America (Osterhoff, 1979; Bertram, 1992). Ostrich feather was ranked fourth in value after gold, diamonds and wool, on the list of exports from the then Union of South Africa. Farm ostriches are called Struthio camelus var. domesticus (Hallam, 1992; Hildebrandt and Raucher, 1999). Ostrich farming has been rapidly expanded in Worldwide to produce usable products such as meat, hides, feathers, and 
eggs. Ostrich raising needs experience and information from farmers and the successful ostrich farming is largely dependent on the ability of farmers to rear sufficient numbers of viable and healthy chicks (Christensen and Nielsen, 2004). The main products obtained from ostriches are plumes (feathers), ostrich skin and a variety of meat products, for example, the liver, the heart and fresh meat,health care products (ostrich fat) (Jones et al., 1997). Feathers are used in the household and motorcar industries as feather dusters (Hastings, 1991). Ostriches are being explored for medical and medicinal purposes (Odendaal, 2000). Ostrich environment and its microbial load play a significant role in influencing the growth performance of ostrich and thus affect the quality of ostrich product. Ostrich meat and other products can be sources for human infections and may get contaminated through handling, processing, cooking, packaging and storage. Meat quality is dependent on the entire meat production chain from the farm where animals are conceived to the consumer (Monin and Ouali, 1991). Housing design also contribute to the level of microbes in ostrich bodies as ostriches penned on cement or tiles are restless and defecate readily when compared to those penned on sand. Cement or tiled flooring becomes wet and soiled and when ostriches lie down, expensive body feathers are soiled with faeces and urine (Burger et al., 1995). The environment of a farm as heavy soil and poor drainage often result in animals arriving at the abattoir with muddy feet and abdomens. Dirty skins provide major sources of microbial contamination for the carcase (Edwards et al., 1997). The bacterial pathogens most frequently involved in infectious enteritis of ostriches are: Escherichia coli, Salmonella spp. (Doneley, 2006). Ostrich are susceptible to a number of infectious agents which are common to other avian species (Huchzermeyer, 1998; Cooper and Mahroze, 2004). Salmonella was isolated from ratites birds 5 days to 4 years of age (Vanhooser and Welsh, 1995). Bacterial infections are an important issue in intensive ostrich breeding. The most important thing is a high level of ostriches infection with Escherichia coli, Salmonella spp., Pseudomonas spp. (Wieliczko and Kuczkowski, 2000). Bacteria isolated from respiratory disease in ostriches include Staphylococcus spp., Pasteurella haemolytica, Pseudomonas aeruginosa, Bordetella spp., Haemophilus spp., Streptococcus viridans, Mycoplasma spp. and Chlamydia psittaci (Huchzermeyer 1994). Most of the published reports come from research done with poultry from unknown healthy conditions or from sick birds that were sent to diagnostic centers where, Salmonella spp. was reported to cause mortality in ostrich chicks (Shivaprasad, 1993; Verwoerd, 2000). However, it was reported that immunosuppressed adult ostriches may shed Salmonella spp., contributing to contamination of products during slaughtering process (Karama et al., 2003). Now a day's antimicrobial resistance that's occurs for microbes of animal origin, including food-producing animals, pet and companion animals, fish and other aquatic animals as well as wild animals, has gained particular attention (Schwarz et al., 2010). There are only some specific study was applied on the antimicrobial resistance for isolated microbes from ostriches in Bangladesh. Due to the global expansion of ostrich farming and lack of information about the prevalence of microbes in commonly reared ostrich flock. The present study was designed to assess the bacterial load in oropharyngeal swabs, cloacal swabs and feces of ostrich and to determine the antibiotic susceptibility profiles of identified isolates.

\section{Materials and Methods}

\subsection{Sample collection}

The present study was undertaken at HSTU ostrich farm in Dinajpur District of Bangladesh. Samples were brought to the microbiology laboratory of the Department of Microbiology, Hajee Mohammad Danesh Science and Technology University, Dinajpur, during the period from January to June 2017 for laboratory analysis. A total of 75 samples comprising oropharyngeal swab (25), cloacal swab (25) and faeces (25) were collected from different age ostriches with pre-sterilized cotton swab and immediately transferred into test tube with foil paper containing PBS (phosphate buffer solution). Thermo flask containing ice was used to transport the samples from the collection site to Microbiology laboratory for analysis.

\subsection{Experimental layout}

The entire study is divided into three steps. The first step includes the total viable counts of the collected samples. The second step includes isolation and identification of the bacteria from the samples by cultural, morphological and biochemical test. Third step includes evaluation of antibiotics sensitivity against the isolated bacteria.

\subsection{Microbial assessment of the collected samples}

Samples were collected and each of the samples were diluted with distilled water as $10^{-1} 10^{-2} 10^{-3} 10^{-4} 10^{-5} 10^{-6} 10^{-}$

${ }^{7} 10^{-8}$ and $10^{-9}$. Then $1 \mathrm{ml}$ sample was taken and spread in Plate count agar (PCA) plate following the spread-plate 
method and incubate at $37^{\circ} \mathrm{C}$ for 24 hours. The number of organisms per $\mathrm{ml}$ of original culture is calculated by multiplying the number of colonies counted by the dilution factor:

Number of cells per $\mathrm{ml}=$ number of colonies $\times$ reciprocal of the dilution factor.

\subsection{Cultivation and isolation of organisms}

Samples were collected and each of the samples diluted with distilled water as $10^{-1}, 10^{-2}, 10^{-3}, 10^{-4}, 10^{-5}$ and $10^{-6}$ and inoculated into nutrient agar. Then the petri dishes were marked properly and incubated at $37{ }^{\circ} \mathrm{C}$ for 24 hours aerobically in bacteriological incubator. Then sub-cultured onto the MacConkey, SS agar, MSA agar and nutrient agar by streak plate method (Cheesbrough, 1985) to observe the colony morphology of E. coli, Salmonella spp., Staphylococcus spp. and Bacillus spp. These bacteria were repeatedly sub-cultured onto MacConkey, SS agar, MSA agar and nutrient agar until the pure cultures were obtained. Bacteriological examinations were carried out using standard method for aerobic bacteria (Brown, 2005). Pure cultures were achieved as per procedures described by OIE (2000), Merchant and Packer (1967).

\subsection{Identification of associated bacteria}

Isolated organisms were subjected to various biochemical tests (Sugar fermentation test, Oxidase test, Catalase test, Indole test, MR Test, Voges-proskauer test, Simmon's citrate, Triple sugar iron agar, Mortility Indole Urease test and Selenite broth) as per the standard methods described by Cheesbrough (1985).

\subsection{Antibiotic sensitivity test against isolated microbes}

To determine the drug sensitivity and resistance patterns of isolated organisms, we used different types of commercially available antimicrobial discs (Mast diagnostics Mersey side, UK.). The antibiotic resistance was determined by Kirby-Bauer disc diffusion technique using Mueller-Hinton agar (Difco), according to the recommendations of National Committee for Clinical Laboratory Standards (CLSI 2011). After overnight incubation at $37{ }^{\circ} \mathrm{C}$, the diameter in millimeters of the zones of inhibition around each of the antimicrobial discs was recorded and categorized as resistant or sensitive in accordance with company recommendations. E. coli, Salmonella spp., Staphylococcus spp., and Bacillus spp. isolates were tested for sensitivity to Levofloxacin $(5 \mu \mathrm{g})$, Penicillin (10 units), amoxicillin $(30 \mu \mathrm{g})$, Cefxime $(5 \mu \mathrm{g})$, Feridoxin $(10 \mu \mathrm{g})$, Ceftriaxone $(30 \mu \mathrm{g})$, Chloramphenicol $(30 \mu \mathrm{g})$, Gentamicin $(10 \mu \mathrm{g})$, Nalidixic acid $(30 \mu \mathrm{g})$, Vancomycin $(30 \mu \mathrm{g})$, Azithromycin $(15$ $\mu \mathrm{g})$, Eryhromycin $(15 \mu \mathrm{g})$ and tetracycline $(30 \mu \mathrm{g})$.

\subsection{Statistical analysis}

Data were analyzed using SPSS version 21 . The chi-square $(\chi 2)$ test was used to assess statistical differences between the groups. A p-value less than 0.05 were statistically considered significant.

\section{Results}

\subsection{Microbial assessment of collected samples by total viable counts}

During the study period a total 75 (25 orapharyngeal swab, 25 cloacal swabs and 25 feces) samples were collected from different ages of ostrich for total viable counts expressed as CFU which were shown in Table 1. In every case the average colony (CFU) were counted at 30 days interval. In case of orapharyngeal swab the average colony count on 90 days ( 3 months) were $1.87 \times 10^{9} \pm 0.037$ followed by 120 days were $1.52 \times 10^{9} \pm 0.054$, 150 days were $1.38 \times 10^{9} \pm 0.029,180$ days were $1.38 \times 10^{9} \pm 0.029$ and 210 days were $0.9 \times 10^{9} \pm 0.04$ respectively. In case of cloacal swab the average colony count on 90 days ( 3 months) were $1.54 \times 10^{9} \pm 0.022$ followed by 120 days were $1.52 \times 10^{9} \pm 0.054,150$ days were $1.39 \times 10^{9} \pm 0.01,180$ days were $1.30 \times 10^{9} \pm 0.04$ and 210 days were $0.69 \times 10^{9} \pm 0.019$ respectively. In case of feces swab the average colony count on 90 days ( 3 months) were $1.13 \times 10^{9} \pm 0.027$ followed by 120 days were $1.29 \times 10^{9} \pm 0.038,150$ days were $1.52 \times 10^{9} \pm 0.027,180$ days were $1.62 \times 10^{9} \pm 0.03$ and 210 days were $1.83 \times 10^{9} \pm 0.04$ respectively. 
Table 1. Total viable counts expressed as CFU for 75 samples (orapharyngeal swab, cloacal swab and faeces) of ostriches in different age group.

\begin{tabular}{|c|c|c|c|c|c|c|c|c|}
\hline \multirow{2}{*}{$\begin{array}{l}\text { Sample and } \\
\text { sample size }\end{array}$} & \multicolumn{5}{|c|}{ Age of ostriches } & \multirow{2}{*}{$\begin{array}{l}\text { Mean } \pm \\
\text { SEM } \\
\text { N=25 }\end{array}$} & \multirow{2}{*}{$\begin{array}{l}t \\
\text { test }\end{array}$} & \multirow{2}{*}{$\begin{array}{l}P \\
\text { value }\end{array}$} \\
\hline & $\begin{array}{l}3 \text { months } \\
\mathrm{n}=5 \\
\text { (Mean } \pm \\
\text { SEM) }\end{array}$ & $\begin{array}{l}4 \text { months } \\
\text { n=5 } \\
\text { (Mean } \pm \\
\text { SEM) }\end{array}$ & $\begin{array}{l}5 \text { months } \\
\text { n=5 } \\
\text { (Mean } \pm \\
\text { SEM) }\end{array}$ & $\begin{array}{l}6 \text { months } \\
\mathrm{n}=5 \\
(\text { Mean } \pm \\
\text { SEM) }\end{array}$ & $\begin{array}{l}7 \text { months } \\
\text { n=5 } \\
(\text { Mean } \pm \\
\text { SEM) }\end{array}$ & & & \\
\hline $\begin{array}{l}\text { Oropharyngeal } \\
\text { swab }(n=25)\end{array}$ & $\begin{array}{l}1.87 \times 10^{9} \\
\pm 0.037\end{array}$ & $\begin{array}{l}1.52 \times 10^{9} \\
\pm 0.054\end{array}$ & $\begin{array}{l}1.38 \times 10^{9} \\
\pm 0.029\end{array}$ & $\begin{array}{l}1.11 \times 10^{9} \\
\pm 0.024\end{array}$ & $\begin{array}{l}0.9 \times 10^{9} \\
\pm 0.04\end{array}$ & $\begin{array}{l}1.36 \times 10^{9} \\
\pm 0.38\end{array}$ & 8.10 & 0.001 \\
\hline $\begin{array}{l}\text { Cloacal swab } \\
(n=25)\end{array}$ & $\begin{array}{l}1.54 \times 10^{9} \\
\pm 0.022\end{array}$ & $\begin{array}{l}1.47 \times 10^{9} \\
\pm 0.057\end{array}$ & $\begin{array}{l}1.39 \times 10^{9} \\
\pm 0.01\end{array}$ & $\begin{array}{l}1.30 \times 10^{9} \\
\pm 0.04\end{array}$ & $\begin{array}{l}0.69 \times 10^{9} \\
\pm 0.019\end{array}$ & $\begin{array}{l}1.28 \times 10^{9} \\
\pm 0.34\end{array}$ & 8.39 & 0.001 \\
\hline Faeces $(n=25)$ & $\begin{array}{l}1.13 \times 10^{9} \\
\pm 0.027\end{array}$ & $\begin{array}{l}1.29 \times 10^{9} \\
\pm 0.038\end{array}$ & $\begin{array}{l}1.52 \times 10^{9} \\
\pm 0.027\end{array}$ & $\begin{array}{l}1.62 \times 10^{9} \\
\pm 0.03\end{array}$ & $\begin{array}{l}1.83 \times 10^{9} \\
\pm 0.04\end{array}$ & $\begin{array}{l}1.48 \times 10^{9} \\
\pm 0.27\end{array}$ & 12.02 & 0.00 \\
\hline
\end{tabular}

[SEM means Standard Error Mean]. P value $<0.01$ means significant at $1 \%$ level of significance

\subsection{Results of isolation of bacteria}

The results of isolation of bacteria from ostrich oropharyngeal swab, cloacal swab and faeces were shown in Tables 2, 3, 4 and 5. During the study period a total 75 (25 oropharyngeal swab, 25 cloacal swabs and 25 feces) samples were collected from different ages of ostrich for isolation of bacteria. In case of oropharyngeal swabs, 15 (60\%) Staphylococcus spp., 3 (12\%) Salmonella spp., 6 (24\%) Escherichia coli and 1 (4\%) Bacillus spp. were identified. In case of cloacal swabs, 3 (12\%) Staphylococcus spp., 8 (32\%) Salmonella spp., 11 (44\%) Escherichia coli and 3 (12\%) Bacillus spp. were identified. In case of feces, 2 (8\%) Staphylococcus spp., 10 (40\%) Salmonella spp., 12 (48\%) Escherichia coli and 1 (4\%) Bacillus spp. were identified. Among 75 samples, 29 (38.66\%) Escherichia coli, 21 (28\%) Salmonella spp., 20 (26.67\%) Staphylococcus spp. and 5 (6.6\%) Bacillus spp. were identified. In 25 oropharyngeal swab samples, Staphylococcus spp. was found higher 15 (60\%) than other organisms but Escherichia coli were found higher both in cloacal 11 (44\%) and faecal 12 (48\%) samples.

Table 2. Distribution of bacterial isolates identified on oropharyngial swab, clocal swab \& feaces of ostrich.

\begin{tabular}{lllll}
\hline Bacterial isolets & Oropharyngeal swab & Cloacal swab & Feacal swab & Percentage (\%) \\
\hline Staphylococcus spp. & $15(60 \%)$ & $3(12 \%)$ & $2(8 \%)$ & 26.67 \\
Salmonella spp. & $3(12 \%)$ & $8(32 \%)$ & $10(40 \%)$ & 28 \\
Escherichia coli & $6(24 \%)$ & $11(44 \%)$ & $12(48 \%)$ & 38.66 \\
Bacillus spp. & $1(4 \%)$ & $3(12 \%)$ & $1(4 \%)$ & 6.67 \\
$\begin{array}{l}\text { Total number } \\
\text { of isolates identified }\end{array}$ & 25 & 25 & 25 & 100 \\
\hline
\end{tabular}

Table 3. Bacterial species isolated from oropharyngeal swab samples of ostrich.

\begin{tabular}{clllll}
\hline Sample size & Isolated bacteria & Positive isolate & Prevalence $(\%)$ & $\chi^{2}$ value & P value \\
\hline \multirow{2}{*}{25} & Staphylococcus spp. & 15 & 60 & & \\
& Salmonella spp. & 3 & 12 & 24.48 & 0.00 \\
& Escherichia coli & 6 & 24 & & \\
& Bacillus spp. & 1 & 4 & & \\
\hline
\end{tabular}

$\mathrm{P}$ value $<0.01$ means significant at $1 \%$ level of significance

Table 4. Bacterial species isolated from Cloacal swab samples of ostrich.

\begin{tabular}{llllll}
\hline Sample size & Isolated bacteria & Positive & Prevalence (\%) & $\mathbf{2}_{\chi}$ value & P value \\
\hline \multirow{2}{*}{25} & Staphylococcus spp. & 3 & 12 & & \\
& Salmonella spp. & 8 & 32 & 9.97 & 0.019 \\
& Escherichia coli & 11 & 44 & & \\
& Bacillus spp. & 3 & 12 & & \\
\hline
\end{tabular}

$P$ value $>0.01$ means significant at $5 \%$ level of significance 
Table 5. Bacterial species isolated from faces samples of ostrich.

\begin{tabular}{llllll}
\hline Sample size & Isolated bacteria & Positive isolate & Prevalence (\%) & $\chi^{2}$ value & P value \\
\hline \multirow{5}{*}{25} & Staphylococcus spp. & 2 & 8 & & \\
& Salmonella spp. & 10 & 40 & \multirow{2}{*}{19.79} & 0.00 \\
& Escherichia coli & 12 & 48 & & \\
& Bacillus spp. & 1 & 4 & & \\
\hline
\end{tabular}

$\mathrm{P}$ value $<0.01$ means significant at $1 \%$ level of significance

\subsection{Identification of bacteria by different bacteriological methods}

\subsubsection{Results of cultural examination}

The cultural characteristics of E. coli, Salmonella spp., Staphylococcus and Bacillus spp., on various selective media are presented in Table 6.

Table 6. The results of cultural characteristics of the bacteria isolated from oropharyngeal swab, cloacal swab and faeces of ostrich.

\begin{tabular}{llll}
\hline Serial No. & Name of bacteria & Name of media & Colony characteristics \\
\hline 01 & E. coli & Nutrient Agar & Large, mucoid, white colony \\
& & MacConkey's Agar & Produce large mucoid rose pink colony \\
& EMB agar & Metallic sheen(greenish black) colony \\
02 & Staphylococcus spp. & Nutrient Agar & Black colour/ non-colour smooth, glistening colony \\
& & Staphylococcus & Yellow colony \\
& Agar No.110 & \\
& Slood Agar & B-hemolytic colony \\
03 & Bacillus spp. & MacConkey agar & Small, white, translucent dew drop like colony \\
& & SS agar & Opaque, smooth, round with black centered colony \\
04 & & Nutrient Agar & Grayish white color with Medusa head colony \\
& & Soft Agar & Thick, grayish white or cream colored colony \\
\hline
\end{tabular}

3.3.2. Results of biochemical tests of samples isolated from oropharyngeal swab, cloacal swab and faeces of ostrich

The results of biochemical tests of isolated bacteria are shown in Table 7.

Table 7. Results of biochemical tests for the representative isolates.

\begin{tabular}{lllllllllll}
\hline Serial No. & OXI & CT & Ind & MR & VP & SC & TSI & MIU & SB & Result \\
\hline 1 & - & + & + & + & - & - & YY & + & + & E. coli \\
2 & - & + & - & + & + & + & YR & + & + & Salmonella \\
3 & - & + & - & + & - & - & YR & + & - & Staphylococcus spp. \\
4 & - & + & - & - & - & - & YR & + & - & Bacillus spp. \\
\hline
\end{tabular}

[Legands: $+=$ positive, $-=$ negative, OXI= Oxidase, CT= Catalase, Ind= Indole, MR= Methyl Red, VP= Voges-Proskaur, $\mathrm{SC}=$ Simmons Citrate, $\mathrm{TSI}=$ Triple Sugar Iron, MIU=

Motility Indole Urease, SB= Selenite broth]

\subsection{Results of antibiotic sensitivity test}

A total of four isolates such as E. coli, Salmonella spp., Staphylococcus spp. and Bacillus spp. obtained from oropheryngial swab, clocal swab and feces samples of ostrich were subjected to antibiotic sensitivity assay as shown in Tables 8 and 9. 
Table 8. Antimicrobial susceptibility profile of E. coli and Salmonella spp.

\begin{tabular}{|c|c|c|c|c|}
\hline \multirow{2}{*}{ Antimicrobial agents } & \multicolumn{2}{|c|}{ E. coli } & \multicolumn{2}{|c|}{ Salmonella spp. } \\
\hline & $\begin{array}{l}\text { Diameter of } \\
\text { of zone inhibition } \\
\text { (mm) }\end{array}$ & Interpretation & $\begin{array}{l}\text { Diameter of zone } \\
\text { of inhibition }(\mathrm{mm})\end{array}$ & Interpretation \\
\hline Levofloxacin & 17 & $\mathrm{~S}$ & - & $\mathrm{R}$ \\
\hline Amoxicillin & - & $\mathrm{R}$ & - & $\mathrm{R}$ \\
\hline Feridoxin & - & $\mathrm{R}$ & - & $\mathrm{R}$ \\
\hline Cefxime & - & $\mathrm{R}$ & - & $\mathrm{R}$ \\
\hline Chloramphenicol & - & $\mathrm{R}$ & - & $\mathrm{R}$ \\
\hline Gentamicin & 24 & I & - & $\mathrm{R}$ \\
\hline Nalidixic acid & - & $\mathrm{R}$ & - & $\mathrm{R}$ \\
\hline Azithromycin & - & $\mathrm{R}$ & 18 & $\mathrm{~S}$ \\
\hline Erythromycin & 22 & $\mathrm{~S}$ & - & $\mathrm{R}$ \\
\hline Tetracycline & - & $\mathrm{R}$ & - & $\mathrm{R}$ \\
\hline Ceftriaxone & - & $\mathrm{R}$ & - & $\mathrm{R}$ \\
\hline Vancomycin & 15 & $\mathrm{~S}$ & - & $\mathrm{R}$ \\
\hline
\end{tabular}

Note: $\mathrm{S}=$ Sensitive, R=Resistant, I=Intermidate.

Table 9. Antimicrobial profile of Staphylococcus spp. and Bacillus spp.

\begin{tabular}{|c|c|c|c|c|}
\hline \multirow{2}{*}{ Antimicrobial agents } & \multicolumn{2}{|c|}{ Staphylococcus spp. } & \multicolumn{2}{|c|}{ Bacillus spp. } \\
\hline & $\begin{array}{l}\text { Diameter of } \\
\text { zone of inhibition } \\
(\mathrm{mm})\end{array}$ & Interpretation & $\begin{array}{l}\text { Diameter of zone } \\
\text { of inhibition }(\mathrm{mm})\end{array}$ & Interpretation \\
\hline Levofloxacin & 18 & $\mathrm{~S}$ & 18 & $\mathrm{~S}$ \\
\hline Penicillin & - & $\mathrm{R}$ & - & $\mathrm{R}$ \\
\hline Amoxicillin & - & $\mathrm{R}$ & - & $\mathrm{R}$ \\
\hline Feridoxin & - & $\mathrm{R}$ & - & $\mathrm{R}$ \\
\hline Cefxime & 19 & $S$ & 19 & $\mathrm{~S}$ \\
\hline Chloramphenicol & - & $\mathrm{R}$ & - & $\mathrm{R}$ \\
\hline Gentamicin & 14 & $\mathrm{~S}$ & 14 & $\mathrm{~S}$ \\
\hline Nalidixic acid & - & $\mathrm{R}$ & - & $\mathrm{R}$ \\
\hline Azithromycin & - & $\mathrm{R}$ & - & $\mathrm{R}$ \\
\hline Erythromycin & 22 & $S$ & 22 & $\mathrm{~S}$ \\
\hline Tetracycline & - & $\mathrm{R}$ & - & $\mathrm{R}$ \\
\hline Ceftriaxone & - & $\mathrm{R}$ & - & $\mathrm{R}$ \\
\hline Vancomycin & 17 & $\mathrm{~S}$ & 17 & $\mathrm{~S}$ \\
\hline
\end{tabular}

Note: $\mathrm{S}=$ Sensitive, $\mathrm{R}=$ Resistant, $\mathrm{I}=$ Intermidate.

\section{Discussion}

Ostrich farming system is not common in Bangladesh. At HSTU ostrich farms they fed many type of food items like vegetables, leaves, tubewell water which are contaminated with different type of microorganisms leading to frequent infections. Perhaps this was the first study about ostrich in Dinajpur, Bangladesh to monitor the microbial assessment in oropharyngeal swab, cloacal swab and fecal samples of ostrich and also update knowledge on antimicrobial sensitivity of isolated organisms. In the present study, the result of total viable counts was expressed by CFU (colony forming unit). In every case the average CFU was counted at 30 days interval. The mean colony counts in oropharyngeal swab, cloacal swab and feces samples were $1.36 \times 10^{9} \pm 0.38$, $1.28 \times 10^{9} \pm 0.34$ and $1.48 \times 10^{9} \pm 0.27$, respectively. The present findings revealed that the total viable count recorded in oropharyngeal swab and cloacal swab shown higher in three (3) months age group and gradually lower in 7 months age. On the other hand, the results of total viable count was increased in feces samples with the increased age of ostrich.

In a previous study there were very little information about total viable colony count in ostrich and the result was aggred with Cook et al. (1997). In Newzeland detected a maximum areas viable count was $\log 2.11$ for ostrich carcass. But in USA shown that counts was about log 6.0 for ostrich carcass (Sofos et al., 1999). Gill et 
al. (2000) estimated log mean APC numbers of ostriches and emus were greater than the corresponding values estimated for beef carcasses. In this study, the results shown that ostriches were potential reservoirs for Salmonella spp., E. coli, Staphylococcus spp. and Bacillus spp. These bacteria are important pathogens for human and other animals. Overall cultural prevalence of $E$. coli isolates were 29 (38.66\%) which was lower than the observation of Gill and Jones (1996). E. coli was the most frequently isolated bacterium in the study. This finding correlates with the observation that $E$. coli is the predominant enteric bacteria isolated from ostrich chicks suffering from enteritis (Verwoerd et al., 1998). In the present study, overall cultural prevalence of Salmonella spp. was 20 (26.67\%). More (1996) and Welsh et al. (1997b) studied in 3 different serotypes of Salmonella isolated from ostriches. Concerning the occurrence of $S$. aureus which is not usually detected in the intestinal tract of ostrich (Notermans et al., 1982) but in this study Staphylococcus spp. 3(12\%) observed in cloacal swab. In this study, the overall cultural prevalence of Bacillus spp. was 5 (6.6\%) which was little lower than the findings of Hassan et al. (2016).

On antibiogram study isolated Escherichia coli were more sensitive to Levofloxacin, while more resistant to Tetracycline, Penicillin, Chloramphenicol, Erythromycin, Feridoxin, Amoxicillin, Gentamicin, Ceftriaxone, Nalidixic acid, Azithromycin, Vancomycin. Sahinduran (2004) stated in his study that isolated Escherichia coli were the most susceptible to amoxycillin and clavulanic acid combinations. In this study isolated Salmonella spp. were sensitive to Azithromycin, while resistant to Tetracycline, Penicillin, Chloramphenicol, Erythromycin, amoxicillin, Amoxicillin, Gentamicin, Ceftriaxone, Nalidixic acid, Levofloxacin and Vancomycin. But in a previous study by Yadav et al. (2017) at Chittagong, Bangladesh Salmonella isolates from ostriches were found resistance to Amoxicillin, Ampicillin, Oxytetracycline, Cotrimoxazole, Azithromycin and Erythromycin followed by Colistin sulfate $83.33 \%$, Pefloxacin 38.88\%, Enrofloxacin $38.88 \%$, Gentamycin $11.1 \%$ and Ceftriaxone 0\% which was relevant to the study. In a previous study by Hassan et al. (2014) at Chittagong, Bangladesh, Salmonella isolates from layer poultry were found $100 \%$ resistant to Amoxicillin and Tetracycline followed by Enrofloxacin (87.5\%), Ciprofloxacin (87.5\%), Pefloxacin (87.5\%), Doxycycline (50\%), Colistin $(50 \%)$ and Kanamycin (50\%) and isolates showed high sensitivity (100\%) to Gentamicin and Neomycin are similar to our findings. In this study, isolated Staphylococcus spp. and Bacillus spp. were more sensitive to Levofloxacin, Azithromycin, Cefxime, Erythromycin, Vancomycin and Erythromycin respectively while more resistant to tetracycline, Penicillin, Chloramphenicol, amoxicillin and amoxicillin, respectively. Sahinduran (2004) also stated that on his antibiogram results, isolated microbial agents were the most susceptible to amoxycillin and clavulanic acid combinations. In present study, a range of bacterial flora was isolated from the samples, indicating the presence of these organisms in the healthy ostriches that living in HSTU ostrich farm. These findings was in accordance with some reports about birds and ruminant that reported as potential pathogens for humans and animals (Bengmark, 1998).

In order to obtain the appropriate microbial assessment in different samples of ostrich, this study should be continued by high population in different farms with defined variable into the future.

\section{Conclusions}

The results collected during this study indicate that ostriches are susceptible to a number of microbial agents which are common to other avian species. Ostrich oropharyngeal swab is one of the most important sources of Staphylococcus spp, cloacal swab and feacal samples are the sources of E. coli and Salmonella spp, few percentage of Bacillus spp found every sample in ostrich farm. These isolated organisms may be transmitting to human. The prevalence of these microorganism in ostrich environment depend mainly on the degree of the hygienic measures used in each farm. Poor sanitation and handling of captive ostrich could be a source of contamination. Antibiotic resistance of isolated organisms are also considered as an important problem. Proper choice of antimicrobials and strict bio-security measure should be relevant for the ostrich farms. As ostrich farming is gaining attention as an emerging industry in Bangladesh, therefore this type of study will be beneficial for the stockholders and prescribers and also ostrich owners. Finally, it may be concluding that the logical use of antibiotics must be adopted in ostrich farms reared in Bangladesh for prevention the appearance of multidrug resistance bacteria. Moreover proper measures should be taken to ward off zoonotic diseases in peoples who are related to ostrich farming.

\section{Acknowledgments}

This research work was supported by Department of Microbiology, Hajee Mohammad Danesh Science and Technology University, Dinajpur, Bangladesh. 
Conflict of interest

None to declare.

\section{References}

Bertram BCR, 1992. The ostrich communal nesting system. In: Krebs J.R. \&Clutton Brocks T.H. (Eds), Monographs in Behaviour and Ecology, Princeton University Press, Princeton New Jersey, 30-32.

Bengmark S, 1998. Ecological control of the gastrointestinal tract. The role of probiotic flora. Gut, 42: 2-7.

Brown AE, 2005. Benson's Microbiological Applications: Laboratory Manual in General Microbiology (Reidy, P.E. and Fornango, J.S., Eds.). McGraw-Hill, Inc., New York.

Burger WP, B Peyrot, A Bekker, B Swart, LP Theron, M De-Jesus and E Van Zyl, 1995. Microbiological assessment of two methods of ostrich lairage - on sand and cement flooring at an ostrich abattoir. Directorate of Veterinary Public Health, Private Bag X138, Pretoria, 0001, South Africa.

Cheesbrough M, 1985. Medical laboratory manual for tropical countries.I.stedi.Vol 2. Microbiology. English Language Book Society, London. pp. 400-480.

CLSI, 2011. Performance Standards for Antimicrobial Susceptibility Testing; TwentyFifth Informational Supplement. CLSI document M100-S25. Wayne, PA: Clinical and Laboratory Standards Institute.

Christensen JW and BL Nielsen, 2004. Environmental enrichment for ostrich, Struthiocamelus, chicks. Animal Welfare, 13: 119-124.

Cook RL, SC Hathaway, JCL Harrisson and NH Armitage, 1997. Microbial baselinerd survey of New Zealand bovine carcasses: A Preliminary Report. Presented at 43 International Congress of Meat Science and Technology, 23-1 August, Auckland, Australia.

Cooper RG and KM Mahroze, 2004. Anatomy and physiology of the gastro-intestinal tract and growth curves of the ostrich (Struthio camelus). Anim Sci J., 75: 491-498.

Doneley B, 2006. Diseases of the gastrointestinal tract. Pages 976-980 in Clinical Avian Medicine, Vol. 2.G. J. Harrison, and T. L. Lightfoot, ed. Spix Publishing, FL.

Edwards D, AM Johnston and GC Mead, 1997. Meat Inspection: An overview of present practices and future trends. The Veterinary Journal, 154: 135-147.

Gill CO and T Jones T, 1996. Microbiological sampling by excision or swabbing. Journal of Food Protection, 63: 167-173.

Gill CO, T Jones, J Bryant and DA Brereton, 2000. The microbiological conditions of the carcasses of six species after dressing at a small abattoir. Food Microbiology, 17: 233-239.

Hallam MG, 1992. The topaz introduction to practical ostrich farming. Superior Print and Packaging, 44A Plymouth Road, Harare, Zimbabwe, 2.

Hastings MY, 1991. Ostrich Farming. "Biordah” Winchelsea Vic, Armidale, New South Wales 2351, Australia, 31.

Hassan GC, Z Payman, N Donya, MA Ebrahim and BA Hamed, 2016. Identification of ostriches (Struthio camelus) gastrointestinal bacterial floraand characterization of the antibioticresistance profile of Salmonella serovars isolated from North-West of Iran. Academic Center for Education, Culture and Research, 1: 1.

Hildebrandt G and K Raucher, 1999. Ostrich husbandry in Germany/Ostrich meat from Namibia - A case study. Berliner und Munchener Tierarztliche Wochenschrift, 112: 146-152.

Huchzermeyer FW, 1994. Ostrich Disease. Agricultural Research Council, Pretoria, South Africa, 175-192.

Huchzermeyer FW, 1998. Disease of ostriches and other ratites. Agricultural Research Council, Onderstepoort Veterinary Institute, Republic of South Africa, 304.

Jones SM, WM Robertson and D Breton, 1997. Ostrich meats. Agriculture and Agri-food Canada, Lacombe Research Centre, TOC1 SO Alberta, Canada 1-5.

Karama M, A Jesus, and CVeary, 2003. Microbial quality of ostrich carcasses produced at an export-approved South African abattoir. J. Food Prot., 66: 878-881.

Monin G and A Ouali, 1991. Muscle differentiation and meat quality In: Lawrie R (Ed) Developments in meat science, Elsevier Applied Science, London, 89-157.

More SJ, 1996. The performance of farmed ostrich chicks in eastern Australia. Prev. Vet. Med., 29:91-106.

Merchant IA and RA Packer, 1967. Veterinary bacteriology and virology, 7th edn. The Iowa University Press, Ames, Iowa, USA. 286-306.

Notermans S, J Dufresne and WJ Van Leeuwen, 1982. Contamination of broiler chickens by Staphylococcus aureus during processing; incidence and origin. Journal of Applied Bacteriology, 52: 275.

Office International des Epizooties (OIE), 2000. Manual of standards for diagnostics tests and vaccines. 
Odendaal L, 2000. The production and export of ostrich meat. National Department of Agriculture, National Directorate of Veterinary Services, Private Bag X138, Pretoria, 0001, 1-53.

Osterhoff DR, 1979. Ostrich farming in South Africa. World Review of Animal Production, 6: 19-30.

Sofos JN, SL Kochevar, JO Reagan and GC Smith, 1999. Extent of carcass contamination with Escherichia coli and probabilities of passing US regulatory criteria. J. Food Prot., 62: 234-238.

Sahinduran S, 2004. Isolation of Escherichia coli and Staphylococcus aureus from ostriches with conjunctivitis and respiratory disease. Revue Méd. Vét., 155: 167-169.

Shivaprasad HL, 1993. Neonatal mortality in ostriches: an overview of possible causes. Association of Avian Veterinarians, 282-293.

Vanhooser SL and RD Welsh, 1995. Isolation of Salmonella species from ratites. J. Vet. Diagn. Invest., 7: 268269.

Verwoerd D, A Olivier, M Henton and M Walt, 1998. Maintaining health and performance in the young ostrich: Applications for a manna oligosaccharide. Biotechnology in the feed industry. Proc. 14th Alltech Ann. Symp., Nottingham Univ. Press, Nottingham, UK.

Verwoerd D, 2000. Ostrich diseases. Revue scientifique technique. International Office of Epizootics, 19: 638661.

Welsh RD, RW Nieman, SL Vanhooser and LB Dye, 1997b. Bacterial infections in ratites. Vet. Clin. N. Am. Food A., 92: 992-998.

Wieliczko A and M Kuczkowski, 2000. Selected issues of infections diseases in ostrich (Struthio camelus). Medycyna Weterynaryjna, 56: 23-28.

Yadav SK, MD Islam, MD Shafiqul, MD Siddiki and AMAM Zonaed, 2017. Isolation and identification of Salmonella spp. from captive ostriches in Bangladesh by inva gene and sefa gene - specific PCR and detection of their antimicrobial resistance patterns. Annals of Veterinary and Animal Science, 4(1). 